This report was prepared as an account of work sponsored by an agency of the United States Government. Neither the United States Government nor any agency thereof, nor any of their employees, makes any warranty, express or implied, or assumes any legal liability or responsibility for the accuracy, completeness, or usefulness of any information, apparatus, product, or process disclosed, or represents that its use would not infringe privately owned rights. Reference berein to any specific commercial product, process, or service by trade name, trademark. manufacturer, or otherwise does not necessarily constitute or imply its endorsement, recornmendation, or favoring by the United States Government or any agency thercof. The views and opinions of authors expressed herein do not necessarily state or reflect those of the United States Government or any agency thereof.

\title{
184-Inch Synchrocyclotron Decommissioning
}

Dick Reimers, James Haley, and George Hampton

\author{
Accelerator and Fusion Research Division \\ Lawrence Berkeley Laboratory \\ 1 Cyclotron Road \\ Berkeley, California 94720
} Paper presented at the 1989 Particle Accelerator Conference in Chicago, llinois,
March 20 to 23, 1989

This work was supported by the Director, Office of Energy Research, Office of Basic Energy Sciences, Materials Sciences Division of the U. S. Department of Energy under Contract No. DE-AC03$76 S F 00098$ 
184-NCH SYNCHROCYCLOTRON DECOMMISSIONING"

\author{
R. Reimers, J. Halcy, and C. Hampion \\ Lawrence Berkeley Laboratory \\ University of California \\ Bcrkcley, CA 94720
}

\section{4-Inch Synchnocyclotion History and $D$-arription}

Cyclotron design began under Prof. E O. Lawreves in 1940 on a $1225 \mathrm{MS}$ budget. In 1942 the muchine wo uned to electromignetically sppante Unanium 235 from 238. 1946 magnet completion preceded firs opention utilixing the principle of phese stability eccelerating deuterors and diphas. Between 1955 and 1957 it was rebuilt to obthin $730 \mathrm{MeV}$ protons. $460 \mathrm{MeV}$ deuteron, $910 \mathrm{MeV}$ alphes, and He 3 from

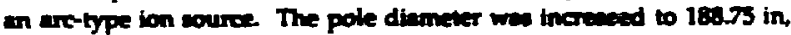
the gap wes reduced to 14 in, and core weight incrosied to 4050 tors. Auxiliary coile wore added. The field wes increvend to $23.4 \mathrm{kG}$.

Power was supplied by DC-producing MC exts Shime mere edded to the poles to obtain a field stronger at the center and decreasing radially uniformily to promole vertiol focraing. The sted vecuum unk was $20 \times 25 \times 4$ ft. RF was sopplied to a dee by a vacuum tube oscillator with a variable capucitor and vibuting reed. A dummy dee grounded to the vectank was employed to provide acoelenting vollage. The 15 -ft-thick walls and 9 -ft-thick roof were $150 \mathrm{Ibs} / \mathrm{cu}$ it reinforaed concrete.

While moet plyyica experiments were mean-related the pi zero meson was discovered here in 1950), other ectivities were biophysies experiments to chudy effects of ionizing radition on living tiseve. pituitary studia, rediotherapy of ocular melanome, and studies of anteriovenow malformations. Nuclear chemistry studies (fission, spallation, tragmentation) were also dose. (Ref. 11

The 184 was last run on December 29,1907 by G. Hampton to provide a biomedical beam. For more himbory see Ref. 2

\section{Deacriotion of its Deopomintionine Tnak}

Cyclotron shutdown freed the dite for contraction. Decommissioning mork included relocetion of Vin de Graff and biomedical programs, ndistion meaverenents, planning extmate preparation, tooling design and procurament, echeduling shipping arrangements, rigging studies, obtaining of permits, wate diposal coondination, and deanup.

A series of planning meetinge was held in the fall of 1987 to assign responsibilities for shielding renoval, syclotron disposal, staffing and safety. The wosk was divided for purposes of ausigning responsibilities, numely (a) thinge outside the shielding and contractors (W. Gurz); (b) the cyclotron and everything inaide the shielding (R Reimen); and (c) the shielding (5. Blair). Helth and Safery (J. Haley) was involved in all ectivities on a dally basis. G. Hampton wes in chage of supavision, building management, and operations. R. Everett we in charge of ribging truck loeding. contuine prepartion, and fork lifte. The maintenence departinent reworked utilities under W. Ganz.

During decomminatoning all the cydowon ports and equipment inside the cyelotron one mere found to have induced radionctivity and were disposed of at the DOE Weatinghouse Henford Company site.

Shielding blocies were surveyed and conesampled to determine redioisotope concentrationa. They mere then segregated for revise. transier to other DOE sites, or landfill based on ectivity content and shape. Items oubide the shielding ware nonactive and conbminutionfree with the excoption of a Uranium spill on the east floor extending down the bench to the pits which was chipped out and removed at were several inches of the induced noor inside the shielding.

\footnotetext{
"This work was supported by the Director, Office of Energy Research, Office of Baric Energy Sciences, Material Sciences Division, of the US. Department of Energy under Contract No. DE-AC03-76SFO0098.
}

1988 Decommissioning Resources Used

\begin{tabular}{lc} 
(Includine shielding work) & Months Effors \\
\hline Riggers \& Mechanieal Technicians & 64 \\
Lebores & 30 \\
Engine-en. Inspecton, Supervisors & 24 \\
Plumbers, Electriciens, Cuperters & 18 \\
Welders & 12 \\
Health and Safety & 12
\end{tabular}

Machiniats, Sheet Metal, Asuemblers,

Mech Repais, Photo, Comnunications

Took and Equipmant. LBL technicians used forklifts as large as 15 tons and a 14ton "cherry picker" crane as well as the two 30-ton building cranes. Tooling to remove the 25 to 4 -in diameter bolts holding the cyclotron together had been built in the 1950s but was discarded. It wes reananufactured because without it, disassembly would have been impossible since the bolts were prestressed to as much as $\mathbf{2 0 0}$ tons apiece to resist magnetic and gravity loads. Plasma cutting equipment was purchsed so that welders could cul copper and duminum. Sawfy or ulto-high-pressure wateriat use were rejected as being to slow or incompatible with waste disposal. Hoppers, crates. drums, and pallets were used to separate metals from non-metals, active iters from insctive ones, toxics from non-toxics, liquids from solids, and to conform to regulatory requirements. See the "Waste" section.

Time nnd Sece. Staging and storage space used was in or near the cyclotron buliding. Schedule:

Project funded, begin mean ove and

Van de Graffs' nemoval

Oct. 1, 1987

Complete removel of meson ove and

Van de Graeff mocelerators

Dec. 21, 1987

Shutdown of gyclotion beam after last rediotherapy treatinent

Dec. 29, 1987

Begin disasembly of cyclotron, shielding. and Biomedical

Completed removal of Biomed facilities and equipment

Feb. 28, 1988

Completed divanembly of cyclotron

Sept. 30.1988

Eunding occurred as part of Light Source site clearance. The extimate for removing items inuide the shlelding was $1121 \mathrm{kS}$ incl. $15 \%$ contingency. Couts were 1105 bs. Shielding costs were also under bodget.

Cyctoron Shielding Total aca 267605 aca $726 \% 4$

Stores, Minc Supplies, Tech. Services

$103 \mathrm{ks} 95 \mathrm{ks} 198 \mathrm{ks}$

Blanket Onders (waste burial)

Puchuse Orders (mostly trucking)

Contrect Labor

Rigging (research techs.)

215

0

Maintenance

(plumbing electricians, corpentry)

112

283

51

183

0

395

Mech. Shops

(tooling fab., welding, culting)

106

ME (engr., plannine mgmt).

Including 40ks Off-budget

Mech. Tech. (diansembly)

Elect. Engro, Elect. Tech, Admin.

Support Burden

Tobl Coat to 1/31/5s

$13 i$
104
55
5
55

6

112

19

3

5




\section{Disessermbly}

Reimers, Rothfuss, Haley, and Burleigh planned disassembly. Most tooling was done by shutown. [Ref. 3]

Cave. Eaxipment. and Brogmm Dikascombly. In the period Oct.Dec. 1987 the meson cave's shielding its Van de Graffs, and experimental equipment were relocated, salvaged, or stored.

Cyclotron disassembly began on Jan. 4. By Feb. 2 the Biomedical treatment cave and patient facility contents including the ISAH patient positioner, radiotherapy equipment, and electronics had been relocated to the Bevalac so that the therapy/research program could continue without interruption utilizing the Bevaluc's new highintensity helium source. The cyclotron roof had been removed concurrently.

Gyclotron Dir-asembly. In Jan., 5000 gal of insettve PCB-free minerai cooling oil were drained from the main coilt By Feb. 28 the beamlines, strong focus section, beam regenerator, and dees had been removed. Shielding was removed at the same time Coondination of the monitoring, segregation, and shipping of the blocks with the disassembly of the cyclotron was one of the important health and safety taskes since the cyolotron fields at times produced backgrounds which made it difficult to measure block setivities sufficiently accurately to segregate properly. In these caves the blocks were taken to a shieided area to be monitored. Utilities were removed throughout the 9-month period. Asbestos-contuining building walls and asbestos in the fiping insulation were removed by contractors. The walls were removed last as they provided shelter, security, and containment during removals.

Surface readings on cyclotron parts varied up to $800 \mathrm{mR}$ so dosimeters were read daly or hourly as required and personnel were rotated to minimize exposure. All cyclotion parts were active. The field was mostly caused by long half-life species such an Cobolt 60 which predominated. The average field in the gap was mearured on fan 5 to be $27 \mathrm{mR} / \mathrm{hr}$ and remined $\mathrm{so}$ undl the most active iters were removed as early as possible in Feb. to minimize exposure during further disussembly of the shims, poles, and vacuum tank during the next monthe. Fortunately, high-intensity proton beams hed ceaved long ago.

The 1955-7 upgrade resulted in a dexign utiltaing the poles as part of the vecuum berrice. This was complex to disadenble as the vacuum tank was trapped between pole diske and there wes only a 14-inch gap into which one hed to crawl to work Numerous pole shims requiring weeks to remove had to be unbolted by technicians in the gap working in fields up to $50 \mathrm{mR} / \mathrm{hr}$. LBL set upper limits of $100 \mathrm{mR} /$ wk avg whole body exposure, $200 \mathrm{mR} / \mathrm{mo}$, and $1000 \mathrm{mR} / \mathrm{yr}$ total whole body exposure. No one received this much. Volunteer technicians, machinists, and asembles rotated through the project so no one bore a disproportionate percent of the total exposure.

Auxiliary coils (100 tons each incl. entrapped pole tpo) were difficult to pull ont of the vactank and took about a month to get out. The 14ton vactank was cut in half in plece, nemoved by the crane, cul up and shipped to the dispoeal site. The lower coil and its cover (150 tons) trok about 5 weeks to remove. There were 11 oily 47-yearold pancakes of up to 16 tons each. The lower pole base was ericased in concrete to provide a support for the cotl cover. There mere aleo many melds needing burning. Two welders were on almost conttnuous duty for 7 months for buming whitever could not be divanembled by other means. Natural gas, oxyecetylene, of plagene undto with H-Ar mix were uned.

Copper coils were plesme cut into piexes 90 inches long that would fit into the specill disposal boxes [Ret. 8) designed for this job by $R$. Tofelshi $6 R$ Reimers as about half of the coll copper was very slightly active with surfice readings up to $100 \mathrm{microR} / \mathrm{hr}$. The copper farthest from the beam had no activity detectable by a meter reading down to $.01 \mathrm{mR} / \mathrm{hr}$ and an attempt to salvege it is underway pending approval by DOE and the State of Calitornia Dept. of Health Services.
Pole bases (300 tons each) had been welded into one piece to resist dynamic and stztic magnetic forces. They were cut up by axyaceiylene and carbon arc units for ease of handling, lasding and shipment.

The etrack on the upper coil (150 tons), upper pole tip (125 tons), and upper pole base was begun in Aug. by the riggers. The last parts were huled away Nov. 38 . The yoke remains to support the crane. Its lower portion has been cast in concrete to upgrade its stability.

\section{Elactrical and Radiation Safcty}

Elactrical. The cyclotron building contained numerous wires, power cables, cords, motors, generators, and signal cables up to 47 years old. In this environment it was fortunate that George Hamplon (who had been associnted with the cyclotron since the early fifties as both an electronics technicien and accelerator operator) was available to serve as on-sibe supervisor of the cyclotron nemoval.

LBL electricians were employed under his guidance to disconnect and reconnect power as needed since the lights, ainms, cranes, etc., still had to function throughout the demolition (a large part of the building and its systems was being demolished concurrently with the cyclotron's demise). No one other than electricins did electrical work. There were no electrical accidents but there were several minor outnges.

Budintion Haznds. Residual gamma radiation levels from induced materials in the cyelotron measured one week after shutdown inside the cyclotron dees were from 5 to $50 \mathrm{mR} / \mathrm{hr}$. The average ficld where the bechnicians worked was $27 \mathrm{mR} / \mathrm{hr}$. The dees' comers were found to be about $800 \mathrm{mR} / \mathrm{hr}$ on the surfece. Inside the shielding on the platform outside the cyctotron the dose rate from the induced shielding plus the induced cyciotron parts wes $0.5 \mathrm{mR} / \mathrm{hr}$ average. Recent cyclotron operations did nol signifieantly contribste to machine activation and primarily long-lived radienuclides semained. Fields exterior to the cyclotion remained fairly constant until the higherlevel active parts were removed.

About $3 \mathrm{~kg}$ of natural uranium which had leached into concrete under the thielding prior to 1553 was found. It was a low-level swipe-free cource of alph until removed and not considered to be a personnel health hazard. The concentration over about 50 square feet averaged 2 microcuries per square foot.

Radintion Safere Proadure. Filn badges were used by all persons on the project. Hand and pocket dosimeters as required were wom by those inside the shielding. Pocket dosimeters were Kit M-187, calibrated per ANSI N12.4-1972. Workers and monitors each read their integrating light-sensitive dosimeters daily (sometimes hourly) and logged the values. Personnel were trained to read and went them properly. Max allowed exposures were $100 \mathrm{mR} / \mathrm{wk}, 200$ $\mathrm{mR} / \mathrm{mo}, 1000 \mathrm{mR} / \mathrm{yr}$ as noted above. To take the cyclotron apurt, workers had to dismentle the muchine from within the gap and vecurum unk aress using time and distance to reduce exposures. Peconnel wae rotated to minimize exposure.

ALARA (as low is rewsonably allowable) exposure rules were explained during rudiation sufety training given to all personnel. This included a presentation on risks, dosimeters and biological monitoring, aedgrinent of a film badge, a lecture on background radiation. biologiosl effect, regulations, and procedures to minimize exposure. Exting, bitering, and nonesential personnel were excluded from ineide the ahielding. Items with surface readings above $5 \mathrm{mR} / \mathrm{hr}$ were moved to a ave to minimize unnecenary exposurs. Radigtion monitors wers on sile during the workdny. Levels down to 10 microroenigen could be read with some meters. liems leaving the building were checked by a monitor using meters having either millior microroentgen/hr detection copabilities.

Air sampling was performed at the site during all dismentling. Samples were changed daily or weekly and asaned for alpha, beta. and gamma. Small concentrations of accelerator activation products, most notably $\mathrm{Co}_{0}$, Eu 152, and $\mathrm{Na} 22$, were found on the air samples. 
No individual sample exceeded DOE's worker-permitted air concentration limits (DAC DOE 5480.11). Overall averages for the 10-month period were $0.3 \%$ DAC for uranium and undet $0.01 \%$ DAC for Co 60 , Eu 152, and $\mathrm{Na} 22$. Personnel were bionssayed at the end of the project. Whole body counts at Donner Laboratory were done on those persons clcsest to activity during the culting and on several others as controls. No unusual activity was sibserved except Cesium peaks belitved attributable to Chemobyl. These Cs peaks were lower than the natural Na peaks and of no concern. High-volume filtered exhaust systems, breathing apparatus, and standby fire personnel were used during torch and plusm cuthing of active items to avoid breathing any volatilized activity. A daily log of exposures was kept for 70 persons. The total personnel dose was 1.629 Rem. 32 persons had positive exposures. The avg dose for these 32 persons was $51 \mathrm{mR}$. The highest total dose for any ose person for the period Jen - Oet 1738 was $165 \mathrm{mR}$.

\section{Wuste}

Waste consisted abmost entirely of skeel, copper, aluminum. reinforced concrete, and cables.

Soncrete \&. Steel Shielding. 494 blocks weighing 8081 tons came from cyclutron and cave walls and roofs. The cyclotron walls consisted of three rings of blocks each five feet thick. Inner ring blocks centained low-level induced material. Some of the middle ring also did, but the outer blocks contained only natural activity. The roof consisted of three layers of noof blocks each three feet thick. The inner layer contained induced low level setivity. Bhair and Haley's disposai study (SLAC. BNL. LANL, and landfill companies were contacted) showed that trucks were the best way to ship blocks as they involved the fewest material transfers and provided more control over the shipment. Some blocks (incl all roof blocke) were retained for LBL reuse, others were stored at LBL or LANL, while unusable shapes were excessed. A large quantity were in the latter caizgory and had activity levels not more than $5 \mathrm{microR} / \mathrm{hr}$ above background. These slightly active concrete shielding blocker were sent to an Alameda County landfill after exhaustive review by Callf. State Dept. of Health Services, DOE SAN, and LaL safety groups, using the draft EPA proposal on naturally-oceurring and acceteratorproduced radiasctive miterial. [Ref. 7] Concrete disposal was coordinated by Haley and Bhir.

Activity. Monitoring of the waste borces' surfaces showed that 140 were below $4 \mathrm{mR} / \mathrm{hr}$. The other eleven (hoiding dee and shim parts) were between 4 and $40 \mathrm{mR} / \mathrm{hr}$ at the box's surface.

Containers. 55-gal drums were too emall to be useful for most items so a 55-1 $\mathrm{t}^{3}$ fire-returdant wooden caulked container $\mathrm{RBL}$. 22!1223C) was designed [Ret 7]. It received Hanford's approval as a dry active waste shipping box. 151 of these (costing $\$ 95-1682$ ea) were shipped. Boxes cut costs by requiring less burial space than drums and also by minimizing culting and shipping coste As boxes were not allowed $>20 \%$ void, we used 24 tons of diatomite fille and vibrated $s 0$ it sifted down to fili voids. Pipes $>1$ in.were crushed. Irregular pieces were strepped to fire-retardant plywood pallets and covered with poly. Items such as alphn emitters were shipped in over 100 dosed 55-gal drams.

Brepantion. Shippine \& Burinl. Solid waste tterre being shipped to the disposal gite had to meet DOE and DOT requirements for preparation, identification, and cleanitiese. Active parts going on pallets were cleaned and wrapped. Packeges mere logged, monitored, and stenciled. Contents and specific activity were recorded. LBL contracted with a certified hauler of solid active waste to move loads averaging 20 tons. Loads over atout $45,000 \mathrm{lbs}$ or $8-\mathrm{ft}$ width needed special permits. Drums were shipped in an enclosed truck Each truck was loaded and monitored so that the ficld at the truck's edge and the driver's location did not exceed levels prescribed by the DOT. Each truck to Hanford had signs indicating activity. Hanford trips cost about $\$ 1200$ and took 2 days. It took 1-2 hrs to get a truck loaded, monitored, and documented. Up to 8 trucks/day were processed for a total of $\mathbf{2 7 4}$ truckloads of shielding and about 45 loads of active waste. Shipping cost varied from $59.67 /$ Ion for local trips, up to $570 /$ ton for Richland. and 572.11 ion for LANL Burial cost S11.66/CF (\$26.07 on 10/1/88).

\begin{tabular}{lrll} 
Wrate Iype & Tons & Destination & $\begin{array}{l}\text { Level a box or } \\
\text { block sturface }\end{array}$ \\
\hline Concrete & 3084 & LBL stor. \& reuse & $2.0 \mathrm{mR} / \mathrm{hr} \max$ \\
Concrete & 2542 & Landfill & $0.005 \mathrm{mR} / \mathrm{hr} \mathrm{max}$ \\
Stel \& Concrete & 2455 & LANL & \\
Cyclotron Parts & 900 & Hanford & $40.0 \mathrm{mR} / \mathrm{hr} \mathrm{max}$
\end{tabular}

\section{Industrial Hygiene Industrial Safaty, and Fir. Safety}

Health and Safety personnel provided gloves, masks, safety shoes and glasses, tinted goggles, vacuums, filkers, car protectors, hard hats, and breathing systems. Rigging activities were the schedulepacing item. Normally one crane was used at a time. Rigging supervivor R. Everett teated and contrelled access to the cranes which were operated by his qualified technicians. $M$. Mikule inspected the crines which were sepaired by LBL maintenance. Forks to 15 tons were used by the riseses. Shop personnel operated 1.5-ton forks. The Fire Marhell monitored activities and provided special equipment and advice. Smull oil fires erupted near fame cutting, but littie smoke and no damige ensued as we had fire watches.

\section{Summang and Acknowled ummants}

Decommissioning has been done safely on budget and schodule.

We thank: D. Rothruss for tooling; R. Burieigh for planning: $R$ Walton for dedication; $R$. Everett and the riggers; W. Oglesby and $R$. Ellis for leadership; $K$. Biscay for monitoring: E. Avila, J. Gonzalez, R. Hainer, and G. Solsza for welding; and 30 shops persons for voluntcering for a tough job.

\section{Relerencess}

1. The 184-Inch Synchrocyctotron," LBL Publication No. 2D, Nov. 1968

2. M. Livingaton and E. MeMillan, Fistory of the Cyclotron," Physics Today 12, 18-34, Oct. 1959.

3. R. J. Burieigh, Disussembly Procedure," LBL Mech. Dept. Engr. Note M6698A. Dec. 1987.

4. K. Biscay, "184 Cyelotron Blog. 6 Foor Plan," LBL Plant Engr. Dapt. Dwg. 486K001A. 1968.

5. R. Burleigh. Facilities Improvernent and Activity Problems on the 184," Williamaburg Conference, 1964.

6. T. Nakae, "184 Cycjotron Gen. Asyy. N.-S. Vertical Section," LBL Mech. Dept. Dwg. 584776, 1953.

7. EPA Draft Proponil: Environmental Stds for the Mgmt. and Land Disposal of Low-Level Radioactive Waste and Naturally Occurring and Accelerator Produced Active Waste." 1987 